\title{
Estimation of Turkey's Import Demand Elasticity for Lint Cotton: An ARDL Bounds Testing Approach
}

\author{
Süleyman KARAMAN, Gökhan TEZEL \\ Akdeniz University, Faculty of Agriculture, Dept. of Agricultural Economics, Antalya/Turkey \\ Received (Geliş): 11.07.2015 \\ Accepted (Kabul): 17.03.2016
}

\begin{abstract}
This study estimates Turkey's import demand model for lint cotton between 1966-2009, utilizing the bounds testing approach to cointegration. The autoregressive distributed lag model (ARDL) demonstrates that there is a long-term relationship between the variables. While the import demand for lint cotton is escalated by income and liberalization policies in the long-run, it is estimated that relative prices and production/consumption coverage ratio will decrease. With the lifting of quotas in 2005, Turkey's textile and apparel sector gained competitive advantage over the competitors in other countries and increased its profitability. Thus, the increase in imports continues as the domestic cotton production fails to meet the demand of the textile sector.
\end{abstract}

Key Words: Lint cotton, liberalization, cointegration, bounds test

\section{Türkiye Lif Pamuk İthalat Talebi Esnekliği Tahmini: Otoregressif Gecikme Dağılımlı Sınır Testi Yaklaşımı}

ÖZET: Bu çalışma, Türkiye lif pamuk ithalat talebi modelini 1966-2009 dönemi için eştümleşimde sınır testi yaklaşımını kullanarak tahmin eder. Otoregressif gecikme dağılımlı model değişkenler arasında uzun dönem ilişkisi olduğunu göstermektedir. Lif pamuk ithalat talebini, uzun dönemde, gelir ve liberalleşme politikaları arttırırken nispi fiyat ve üretimin tüketimi karşılama oranın azaltacağı tahmin edilmiştir. Türkiye tekstil ve konfeksiyon sektörü 2005 yılında kotaların kaldırılmasıyla birlikte diğer ülkelere göre rekabet üstünlüğü sağlayarak karlılığını arttırmıştır. $\mathrm{Bu}$ yüzden, yurtiçi pamuk üretimi tekstil sektörünün talebini karşılamadığından ithalat artışı sürmektedir.

Anahtar Kelimeler: Lif pamuk, liberalleşme, eş tümleşim, sınır testi

\section{INTRODUCTION}

During the past five seasons, Turkey has carried out approximately $9 \%$ of world cotton import $(635,000$ tons) and become the second largest importer of cotton following China (FAO, 2012). Turkey's textile industry continues to expand as it has been increasing its textile and apparel exports to the EU, U.S. and other markets. While the textile industry has been expanding, domestic demand for cotton has risen as well and cotton production began to fail to meet the demand, leading to considerable amounts of cotton imports.

Approximately $80 \%$ of Turkey's cotton import is from the U.S. and Greece. The U.S. has a share of 60$65 \%$ in total cotton import of Turkey. Turkmenistan, India, Brazil, Uzbekistan and Syria are among other countries that have large shares. On the other hand, production of cotton suppliers in Turkey is substantially supported by subsidies. General Sales Manager (GSM) loans are quite influential on cotton import of Turkey from the U.S. GSM-102 three-month/three-year loans are executed by Commodity Credit Corporations that are subject to the Department of Agriculture in countries which are in need of loans with a view to ensure continuity in the consumption of American cotton. Within the scope of the said GSM-102 program that enables the incentivized export of agricultural products with U.S. origin to foreign countries, approximately
$30 \%$ of the loans that have been granted to Turkey since 1999 have been used in cotton imports (MSIT, 2011).

While Turkey was a net exporter of cotton in foreign trade until 1990/91, it started to become a net importer in the following seasons. The increase in cotton import was caused by the facts that the increasing demand of textile industry for cotton could not be met domestically and that the domestic prices were higher than the world prices. In the recent years, textile industry has been adversely affected by fiscal and monetary policies by appreciating Turkish lira and by the global economic crisis of 2008. The objective of this study is to research the effect of such national and international developments on the import demand of textile sector for cotton in the long-run.

\section{Cotton Import Liberalization}

Highly-protective import tariffs and import restrictions were dominant in Turkey's cotton import regime before 1990. Its tariff structure was prohibitory and aimed to protect the domestic cotton production. Within the framework of the World Trade Organization Agreement that went into effect in 1996 and the Customs Union Agreement concluded with the EU, Turkey altered its import regime and adopted the practice of exemption in customs duty. The customs duty exemption that was applied only in the EU and 
EFTA countries in early 1990s as it was the period of transition to the Customs Union began to be applied in all countries after 1996 . Thus, the cotton markets were liberalized and Cotton prices began to be determined by international market factors aside from domestic supply and demand conditions (ICAC, 2008).

With the Customs Union Agreement concluded between Turkey and the EU in 1996, the EU lifted the restrictions applied for textile and apparel products of Turkish origin. This process increased the profitability of textile and apparel sector and led to new investments. While the textile sector's total exports were $\$ 4.3$ billion in 1990 , it rose by 4.4 times in 2005 due to the lifted restrictions in the world's foreign trade of textile and apparels. The increase in exports of textile sector kept on growing and rose by 4.8 times in 2010 relatively to 1990. The increasing demand for cotton due to the expanding textile and apparels sector became unable to be met by domestic production in 1991 and has been met by imports since then. Figure 1 demonstrates the

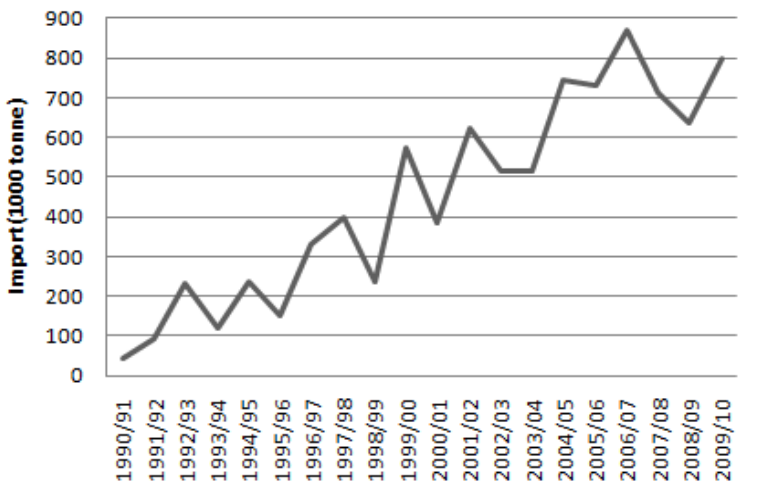

Figure 1. Turkey's lint cotton import

\section{MATERIAL and METHODS}

Import demand model is a standard model derived from imperfect substitution theory. Main presumption of this theory is that neither imports nor exports are perfect substitutes for domestic goods of countries (Dutta and Ahmed, 2004). Each country should be either an exporter or an importer of a traded good, but not both (Goldstein and Khan, 1985). Moreover, imperfect substitution model does not include the importation of inferior goods. Based on the imperfect substitution theory, the import demand model may be briefly described as follows:

As consumers maximize their utility depending on their limited budget according to the conventional theory of demand, the import demand is a function of domestic income, domestic prices of goods and services or cross prices and prices of imports or own prices. Microeconomics theory regards demand functions as homogenous of degree zero in monetary income and prices (Rhomberg, 1973; Deaton and Muellbauer, 1980).

This study considers the import demand for lint cotton as a single equation model. Relative price of import, production/consumption coverage ratio, income (GDP), which affect the demand for lint cotton, as well past 20 years of Turkey's cotton import. While the cotton import of Turkey was 92 thousand tons in the marketing year of $1990 / 91$, it rose by 4.2 times in the marketing year of $1995 / 96$ and by 8.7 times in the marketing year of 2009/10, and reaching a total amount of 800 thousand tons. Consequences of import liberalization can be measured by import penetration ratio. It is the ratio of cotton import to domestic consumption of cotton (Gazanfer, 2004).

Import penetration ratio for cotton is demonstrated in Figure 2. While the import penetration ratio for cotton was $8.5 \%$ in the marketing year of $1990 / 91$, it rose to $65.6 \%$ in the marketing year of $2009 / 10$. Cotton import liberalization led to the result that the textile sector began to meet its demand for cotton from foreign countries which had lower prices than Turkey. Furthermore, long lint cotton, which is needed by textile and apparels sector, has been supplied by imports.

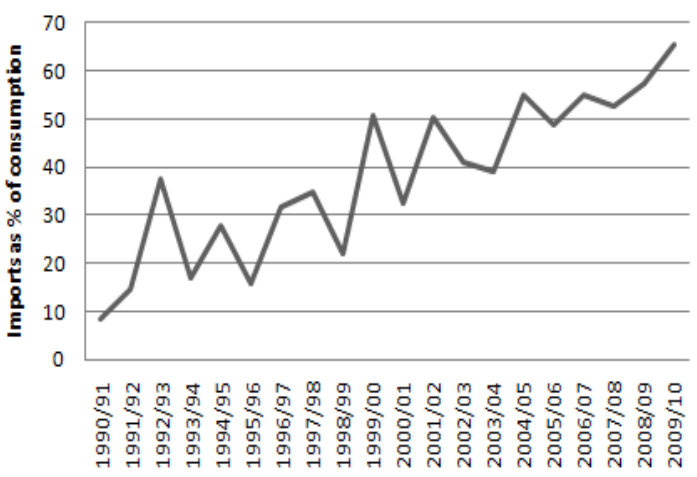

Figure 2. Import penetration ratio for lint cotton

as dummy variables are included in the model. Longterm lint cotton import function in logarithmic form is as follows:

$$
\ln M_{t}=\propto_{0}+\propto_{1} \ln Y_{t}+\propto_{2} \ln R P_{t}+\propto_{3} \ln R P C_{t}+
$$

$\propto_{4} D_{t}+u_{t}$

Here, $\ln M$ in period $t$ is the natural logarithm of the real quantity of lint cotton import; $\ln Y$ is the natural logarithm of Turkey's real domestic income; and lnRP is the logarithm of the relative price. Relative price is the ratio of the price of the imported good to that the domestic good in the same currency. Formulation of prices in relative terms implies two things. First one suggests that domestic and imported lint cotton are imperfect substitutes. Second one is that it prevents a possible linearity that may occur between price terms. The use of relative prices is common in many applied studies on import demand (Abbott and Seddighi 1996; Bahmani-Oskooee and Kara, 2003). $\operatorname{lnPRC}$ is the natural logarithm of production/consumption coverage ratio. Dummy variable (D) is included in the model in order to capture the effect of liberalization policies on import demand. Dummy variable is 0 for the period of 1966-1989 and 1 for 1990-2009. 
In Equation (1), $\propto_{0}$ is the intercept and $\propto_{1}, \propto_{2}, \propto_{3}$ and $\propto_{4}$ are the elasticity coefficients for the relevant variables. $u_{t}$ is the error term which has a constant variance and zero mean and is assumed to be normally distributed. In Equation (1), prior expected signs of the first two variables depend on the conventional theory of demand (Leamer and Stern, 1970). According to this theory, coefficient of real income $(\mathrm{Y})$ is expected to be positive $\left(\propto_{1}>0\right)$ and coefficient of relative prices (RP) is expected to be negative $\left(\propto_{2}<0\right)$. Additionally, coefficient of production/consumption coverage ratio (RPC) is expected to be negative $\left(\alpha_{3}<0\right)$ and coefficient of the dummy variable is expected to be positive $\left(\propto_{4}>0\right)$.

In the case that the time series variables in the import demand model, $\ln \mathrm{M}, \ln \mathrm{Y}, \operatorname{lnRP}$ and $\operatorname{lnRPC}$ have unit roots, it is required to take their first difference so as to make the series stationary. The procedure of taking the first difference leads to the loss of valuable "longterm information" in the data (Maddala, 1992). Cointegration theory introduces the error correction term (EC) into the model. One period lagged error term $\left(\mathrm{EC}_{\mathrm{t}-1}\right)$ integrates the short-term dynamics in the longterm import demand function.

Import demand model is estimated using the yearly time series for the period between 1966 and 2009. Data which is used in the model have been obtained from Turkish Statistical Institute (TSI, 2010; TCEI, 2010 and AEPDI, 2010).

Table 1. ADF unit root tests for stationarity

\begin{tabular}{|c|c|c|c|c|c|}
\hline \multirow{2}{*}{ Variables } & \multicolumn{2}{|c|}{ Level } & \multicolumn{2}{|c|}{ First Differences } & \multirow[b]{2}{*}{ Conclusion } \\
\hline & $\begin{array}{l}\text { Without } \\
\text { trend }\end{array}$ & With trend & Without trend & With trend & \\
\hline $\ln M$ & $-1.174(0)$ & $-2.970(0)$ & $-8.877(0)^{*}$ & $-8.876(0)^{*}$ & $\mathrm{I}(1)$ \\
\hline $\ln Y$ & $-0.889(0)$ & $-2.878(0)$ & $-6.989(0)^{*}$ & $-6.973(0)^{*}$ & $\mathrm{I}(1)$ \\
\hline $\operatorname{lnRP}$ & $-4.778(0)^{*}$ & $-6.366(0) *$ & $-8.825(0)^{*}$ & $-8.715(0)^{*}$ & $\mathrm{I}(0)$ \\
\hline $\operatorname{lnRPC}$ & $0.248(2)$ & $-8.104(0)^{*}$ & $-10.057(1)^{*}$ & $-10.082(1)^{*}$ & $\mathrm{I}(0)$ \\
\hline
\end{tabular}

Notes: Lag length for ADF test is decided based on SIC and are in the parentheses;* indicates that unit root test is rejected at $\% 5$ level, Critical value is -2.931 at $\% 5$ level in the case of only drift; $\quad-3.518$ at $\% 5$ level in the case of drift and slope; probability level (MacKinnon, 1996).

Bounds testing approach can be carried out in two stages. In the first stage of ARDL analysis, it is researched whether there is a long-term relationship in the theoretical model. In order to determine the appropriate number of lags, models with and without trend are estimated and AIC and SBC information criteria are computed for each lag. Furthermore, Langrage Multiplier (LM) test is applied so as to find out whether the residuals have serial correlation. Number of lags is found $\mathrm{p}=2$ in both models with and without trend according to AIC and SBC information criteria. In consequence of the serial correlation LM test conducted on both models with and without trend in this number of lags, and no serial correlation is observed.

\section{RESULTS AND DISCUSSION}

In order to identify the dynamic behaviours of lint cotton import demand, firstly cointegration relations are established and then the error correction model (ECM) is estimated. In the estimation of this model, bounds testing procedure is utilized within the framework of autoregressive distributed lag (ARDL) (Pesaran et al., 2001) Unlike Johansen cointegration test, bounds testing approach does not require a prior unit root test for the variables included in the model (Johansen, 1988; Johansen, 1995). It can be applied regardless of whether the regressors in the model are purely $\mathrm{I}(1)$ or purely $\mathrm{I}(0)$ or mutually cointegrated. However, bounds test cannot be applied when regressors are I(2) or a higher degree. Hence, Augmented Dickey-Fuller (ADF) unit root test is conducted to assure stationarity both in the levels and first differences of all of the four regressors in the model (Dickey and Fuller, 1979). As the case in this study, bounds test is relatively more effective in small or finite sample sizes. Bounds testing approach applies to trend stationary and difference stationary regressors. This approach may also be applied where the explanatory variables are endogenous and it is appropriate for simultaneously correcting the serial correlation of residuals.

Results of the unit root test for the regressors in the lint cotton import demand model are given in Table 1 . According to the results of ADF unit root test, the regressand $\ln \mathrm{M}$ and the regressor $\ln \mathrm{Y}$ are not stationary, whereas the regressors $\operatorname{lnRP}$ and $\operatorname{lnRPC}$ are stationary. In this case, ARDL method can be applied on the lint cotton import demand model.
Thus, since there is not a distinct disaggregation related to trend in both models, no decision may be made regarding the inclusion of the trend into the model.

Subsequently, the bounds testing approach is applied so as to test the long-term relation, that is, whether cointegration exists or not. In the bounds test, it is researched whether the significance of lagged level coefficients is conjointly zero using F-test. Results of the bounds test suggest the presence of a long-term relationship between the variables in the model for $\mathrm{p}=2$ (number of lags) since the F-statistics exceeds the critical value of Peseran et al., 2001 (at 5\% level, c). Results of F-statistics and t-statistics computed for selecting the model with trend or the model without 
trend demonstrate that the models estimated without trend may be appropriate. Thus, it is concluded that the model without trend should be used in short-term and long-term analyses (Table 2).

Table 2. Test of cointegration relationship

\begin{tabular}{|c|c|c|c|c|c|}
\hline \multirow[b]{2}{*}{$\mathrm{p}^{*}$} & \multicolumn{3}{|c|}{$\begin{array}{c}\text { With } \\
\text { deterministic trends }\end{array}$} & \multicolumn{2}{|c|}{$\begin{array}{c}\text { Without } \\
\text { deterministic trends }\end{array}$} \\
\hline & $\mathrm{F}_{\mathrm{IV}}$ & $\mathrm{F}_{\mathrm{V}}$ & $\mathrm{t}_{\mathrm{V}}$ & $\mathrm{F}_{\mathrm{III}}$ & $\mathrm{t}_{\mathrm{III}}$ \\
\hline 1 & $3.638^{b}$ & $3.633^{b}$ & $-3.012^{a}$ & $3.781^{b}$ & $-3.029^{b}$ \\
\hline 2 & $3.112^{\mathrm{b}}$ & $3.649^{b}$ & $-3.625^{b}$ & $4.748^{\mathrm{c}}$ & $-4.514^{c}$ \\
\hline 3 & $2.314^{\mathrm{a}}$ & $2.856^{\mathrm{a}}$ & $-2.670^{a}$ & $2.982^{b}$ & $-3.680^{b}$ \\
\hline For $\mathrm{k}=4$, critical $\mathrm{v}$ & $\begin{array}{r}\text { es (Pesar } \\
F_{1 v}(3 \\
F_{111} \\
t_{111}(-2\end{array}$ & $\begin{array}{l}\text { et al., } 20 \\
, 3.97) \text { a } \\
6,4.01) \\
6,-3.99)\end{array}$ & $\begin{array}{l}F_{v}(3.47, \\
(-3.41,-\end{array}$ & & \\
\hline
\end{tabular}

After determining the presence of long-term relationship between six variables by the bounds testing approach, the following $\operatorname{ARDL}(\mathrm{m}, \mathrm{n}, \mathrm{p}, \mathrm{q}, \mathrm{r})$ is estimated for lint cotton import demand, assuming the number of lags is $2(\mathrm{p}=2)$. The most appropriate ARDL order for lint cotton import demand is based on the minimization of Akaike information criteria. Order of the ARDL model estimated for lint cotton import demand has been determined as $\operatorname{ARDL}(1,2,0,2,0)$. This model is as follows:

$$
\begin{gathered}
\ln M_{t}=31.487+0.445 \ln M_{t-1}+5.837 \ln Y_{t}+ \\
2.626 \ln Y_{t-1}-9.915 \ln Y_{t-2}-2.397 \ln R P_{t}- \\
1.765 \ln R P C_{t}+0.559 \ln R P C_{t-1}-3.164 \ln R P C_{t-2}+ \\
2.858 D_{t}
\end{gathered}
$$

Long-term coefficient estimates of Turkey's import demand for lint cotton are showed in Table 3 . Coefficients of the import demand ARDL model have the expected sign. In this model, coefficients of income, relative prices and dummy variable are significant at $5 \%$ level and coefficient of production/consumption coverage ratio is significant at $10 \%$ level. Ceteris paribus, it is expected that $1 \%$ increase in income may increase the lint cotton imports by $2 \%$ in the long-term. While the expansion of the export volume of the textile and apparels sector for a long time has been increasing its contribution to national income, it also increases the demand for lint cotton.

Relative prices (foreign prices as a proportion of domestic prices) are statistically significant and have a negative effect on import. $1 \%$ increase in foreign prices relatively to domestic prices causes $3 \%$ decrease in import demand for lint cotton. That is, when the increase in import price is higher than the increase in domestic price or in the case that there is an increase in import price, while the domestic price is constant, lint cotton import will fall.

Production/consumption coverage ratio has negative sign and is statistically significant. $1 \%$ decrease in production/consumption coverage ratio in the long-term is expected to cause $2 \%$ increase in import demand for lint cotton. As the domestic production is unable to meet consumption, the production/consumption coverage ratio decreases. This shows that consumption of lint cotton increases. Since lint cotton with sufficient quality is unable to be supplied to the textile sector, the increase in imports goes on. Cotton cultivation lands are expanded to boost the domestic production. However, increases in cotton production costs restrain the increase of cotton production.

The dummy variable is included into the import demand model with a view to determine how the liberalization policies in cotton market affect the cotton import. Coefficient of the dummy variable has a positive sign and is statistically significant. The increase in lint cotton imports relatively to 1990 when the liberalization in cotton market began is also consistent with the results of the model. The lifting of customs duty in cotton import by Turkey in 1994 led to the consequence that the demand that is not met domestically but is met by foreign supplier.

Table 3. Long-run results of Turkey's lint cotton import demand model

\begin{tabular}{lrrrl}
\hline Variables & Coefficients & Std. Error & t-statistics & Prob. \\
\hline Constant & -31.189 & 28.664 & -1.088 & 0.283 \\
$\ln \mathrm{Y}_{\mathrm{t}}$ & 2.120 & 0.912 & 2.325 & $0.025^{* *}$ \\
$\operatorname{lnRP} \mathrm{t}_{\mathrm{t}}$ & -3.057 & 0.869 & -3.518 & $0.001^{*}$ \\
$\operatorname{lnRPC}_{\mathrm{t}}$ & -2.031 & 1.112 & -1.826 & $0.075^{* * *}$ \\
$\mathrm{D}_{\mathrm{t}}$ & 2.175 & 1.074 & 2.025 & $0.049^{* *}$ \\
\hline${ }^{*}$ Statistical significance at 1 \% level, ** Statistical significance at 5\% level & \\
*** Statistical significance at $10 \%$ level & & &
\end{tabular}


Short-term results and diagnostic tests are provided in Table 4. When the short-term coefficients of the import model are examined, coefficient of the income variable is higher than long-term coefficients. In the short-term, coefficients of income (-1), relative prices, production/consumption coverage ratio and dummy variable have the expected signs and these variables have elastic effect on import demand.

Diagnostic tests are conducted in an attempt to test the reliability of the error correction model. With the use of such tests, accuracy and stability of the model as well as heteroscedasticity, normal distribution and autocorrelation of error terms are checked. LM test shows that in the error distribution there is no autocorrelation. Jarque-Bera test for normality indicates that the error terms are normally distributed. The
RESET test indicates that the model is correctly specified. Finally, R-squared is around 0.64. Therefore, it is reasonable to say that the model is well established.

Error correction term, $\mathrm{EC}_{\mathrm{t}-1}$ variable, has negative sign and is statistically significant at $1 \%$ level. In the model, there are no sudden increases in series and the long-term equilibrium is at an attainable level. Error correction term emphasizes that adjustment in import will not occur all of a sudden. It also measures the speed of adjust by the changes in explanatory variables before the import volume converges to equilibrium level. Error correction coefficient $(-0.554)$ indicates that it may take more than 1.5 years for the import volume to converge to equilibrium level after a shock that occurs in Turkey's lint cotton import.

Table 4. Short-run results of Turkey's lint cotton import demand model

\begin{tabular}{|c|c|c|c|c|}
\hline \multicolumn{5}{|c|}{ Dependent variable $: \Delta \ln \mathrm{M}_{\mathrm{t}}$} \\
\hline Variables & Coefficients & td. Error t-sta & Prob & \\
\hline Constant & -31.487 & 33.197 & 0.948 & 0.350 \\
\hline$\Delta \ln Y_{t}$ & 5.837 & 4.613 & 1.266 & 0.214 \\
\hline$\Delta \ln Y_{\mathrm{t}-1}$ & 9.915 & 4.679 & 2.119 & 0.042 \\
\hline$\Delta \ln R P_{t}$ & -2.397 & 0.646 & -3.709 & 0.001 \\
\hline$\Delta \operatorname{lnRPC} C_{t}$ & -1.765 & 0.794 & -2.222 & 0.033 \\
\hline$\Delta \ln R P C_{t-1}$ & 3.164 & 0.778 & 4.065 & 0.000 \\
\hline $\mathrm{D}_{\mathrm{t}}$ & 2.858 & 1.249 & 2.289 & 0.030 \\
\hline$E C_{t-1}$ & -0.554 & 0.109 & -5.096 & 0.000 \\
\hline \multicolumn{5}{|c|}{ Diagnostic tests } \\
\hline$R^{2}$ & 0.641 & & & \\
\hline $\bar{R}^{2}$ & 0.540 & & & \\
\hline$\chi_{\operatorname{Re} s e t}^{2}(1)$ & 6.813 & $(0.426)$ & & \\
\hline$\chi_{L M(1)}^{2}$ & 0.000 & $(0.991)$ & & \\
\hline$\chi_{\text {White }(1)}^{2}$ & 7.001 & $(0.881)$ & & \\
\hline$\chi_{\text {Norm }(2)}^{2}$ & 7.558 & $(0.385)$ & & \\
\hline
\end{tabular}

\section{CONCLUSION}

Long-term dynamic behaviours of Turkey's cotton import have been analyzed utilizing the cointegration and error correction modelling approaches. As the relative prices and production/consumption coverage ratio are stationary and import volume and income variables are stationary at first difference, the relationship between these variables has been examined with the bounds testing approach (Pesaran et al., 2001). It has been found that import volume is cointegrated with other variables in the import demand function.

Long-term results show that an increase in relative prices and production/consumption coverage ratio reduces import and that domestic income has a positive effect on import volume. The dummy variable is related to import liberalization suggests that importation increase with the liberalization in cotton market. Real relative prices, production/consumption coverage ratio, real domestic income (one year lagged) and dummy variable in the error correction model have been found to be significant determinants of the import demand.

As the domestic cotton production fails to sufficiently meet the demand of textile industry, Turkey keeps on being a major market for foreign lint cotton. The domestic lint cotton market can be defined as a competitive market where the government intervention and foreign trade restrictions are not used. Lint cotton market is integrated with international markets where the prices are sensitive to global price changes. Thus, it seems rational that the textile and apparels sector meets its lint cotton need by the imported cotton which has lower prices. However, this applies to short-term; in the long-term it poses a commercial risk as the foreign prices may increase. 
Experiences gained by the textile and apparels sector since 2005 thanks to the agreement entered into with World Trade Organization can compete with those of China, India and Pakistan, which produce most of their cotton need and have price advantage. Although the textile and apparels sector contracted from time to time

\section{REFERENCES}

Abbott A. J., Seddighi, H.R. 1996. Aggregate Imports and Expenditure Components in the UK: An Empirical Analysis. Appl. Econ. 28(9):1119-1125.

AEPDI, 2010. Cotton Situation and Forecasting Report. Agricultural Economics and Policy Development Institute, Ankara, 32s.

Bahmani-Oskooee, M., Kara, O. 2003. Relative Responsiveness of Trade Flows to a Change in Prices and Exchange Rate. Int. Rev. of Appl. Econ. 17(3): 293-308.

Deaton, A., Muellbauer J. 1980. Economics and Consumer Behaviour. Cambridge Univ. Press, Cambridge, 252p.

Dickey, D.A., Fuller, W.A. 1979. Distribution of the Estimate for Autoregressive Time Series with a Unit Root. J. of American Statistical Association, 74(366):427-431.

Dutta, D., Ahmed, N. 2004. An Aggregate Import Demand Function for India: A Cointegration Analysis. Appl. Econ. Letters, 11(10):607-613.

FAO, 2012. Agricultural Statistics. Food and Agriculture Organization, Italy.

Gazanfer, S. 2004. An overview of the Turkish cotton industry with special emphasis on the available tools and techniques of price risk management. Aegean Textiles and Raw Materials Exporters Unions, Izmir.

Goldstein M. and Khan M.S., 1985. Income and Price Affect in Foreign Trade. R. Jones and P. Kenen, Ed., Handbook of International Economics, Amsterdam, North-Holland, 1042-1099. due to implemented monetary policies and crises in Turkey, high quality production and confidence in the product brought a competitive advantage and textile sector has kept on growing. This indicates that Turkey's lint cotton import will continue in the long run

ICAC, 2008. The Country report of Turkey. International Cotton Advisory Committee, U.S.A.

Johansen, S. 1988. Statistical Analysis of Cointegration Vectors. J. Econ. Dynamic Contr., 12(2-3): 231-254.

Johansen, S. 1995. Likelihood-Based Inference in Cointegrated Vector Autoregressive Models. Oxford Univ. Press, Oxford,45p.

Leamer, E. E., Stern R. M. 1970. Quantitative international economics. Allyn and Bacon, International Series in Economics, Boston, MA, $123 p$.

MacKinnon, J.G. 1996. Numerical Distribution Functions for Unit Root and Cointegration Tests. J. Appl. Econometrics, 11(6):601-618.

Maddala, G. S. 1992. Introduction to Econometrics. 2nd Ed, Prentice Hall, Inc., Englewood Cliffs, NJ, 234p.

MSIT, 2011. Cotton Report. Ministry Science, Industry and Technology, Ankara12s.

Pesaran, M.H., Shin, Y., Smith R.J. 2001. Bounds Testing Approaches to the Analysis of Level Relationships. J. of Appl. Econometrics, 16(3):289326.

Rhomberg, R.R. 1973. Towards a General Trade Model. In: Ball, R.J. (Ed.), the International Linkage of National Economic Models. North-Holland, Amsterdam.

TSI, 2010. Statistics Indicators. Turkish Statistical Institute, Ankara, 323s.

TCEI, 2010. Statistical Bulletins. The Commodity Exchange of Izmir, İzmir. 